\title{
PENINGKATKAN KESELAMATAN PELAYARAN DI KOTA BATAM MENGGUNAKAN LOGIKA FUZZY
}

\author{
Sestri Novia Rizki ${ }^{*}$, Handra Tipa ${ }^{2}$ \\ ${ }^{1}$ Prodi Teknik Informatika, Fakultas Teknik dan Komputer, Universitas Putera Batam, \\ Jl. Letjen R. Soeprapto, Batam, Kepulauan Riau, Indonesia 29432. \\ ${ }^{2}$ Prodi Akutansi, Fakultas Ilmu Sosial dan Humaniora, Universitas Putera Batam, \\ Jl. Letjen R. Soeprapto, Batam, Kepulauan Riau, Indonesia 29432 \\ *e-mail: noviasestri@gmail.com
}

\begin{abstract}
At present, many accidents occur on shipping, whether from human negligence or from disasters that occur without human knowledge. Then a rule is made before sailing the parties concerned must check everything related to shipping to avoid accidents. Batam is an archipelago that is connected between many islands, so that sea transportation is the main budget in crossing to various islands. Nowadays there are many accidents such as ships sinking, ships colliding and ships burning, this is due to human negligence. The main objective of this research is to improve shipping safety in Batam City, by observing the waves and engine checks when the ship is about to depart the crew must pay attention to this in order to avoid accidents on the cruise that will be used. So that the passenger safety of the ship is guaranteed. In this study using the mamdani method. The Mamdani method looks for the smallest value to the greatest value. In the Fuzzy method there are three operators, OR, AND and NOT operators. This study uses the OR operator. The steps of this research work, 1. Determine the input variable 2 , determine the fuzzy set, 3 , rule composition, 4 , the final result is in the form of defuzification. The results of this study are in the form of a decisionmaking system in determining the level of maritime shipments and how to prevent them from occurring accidents in the shipping system by taking into account the input variables that have been set such as safety devices, paying attention to waves and always checking ship engines regularly. So that accidents can be avoided. So that the safety of shipping in the city of Batam is more guaranteed.
\end{abstract}

Kata Kunci: Mamdani method, Shipping Safety, Logika Fuzzy.

\section{Pendahuluan}

Batam adalah kota kepuluan yang terletak di kepuluan Riau. Kota Batam di sekelilingi oleh pulau pulau kecil yang lainnya. Untuk alat tranportasi yang digunakan hanya tranportasi laut karena tidak ada akses lain yang menghubungkan dengan pulau lain kecuali kapal. Tujuan utama penelitian ini yaitu memperkecil tingkat kecelakaan kerja dengan memperhatikan hal hal yang berhubungan dengan keselamatan pelayaran seperti mempersiapkan perlengkapan pelayaran, melakukan pengecekan mesin secara rutin, memperhatikan gelombang dan cuaca saat berlayar. Dengan penelitian ini akan menghasikan sebuah output nilai matematika dengan manganalisa system yang ada. Pada saat sakarang ini banyak pihak kapal tidak memperhatikan keselamatan penumpangnya. Penyebab kecelakaan pelayaran seperti kurang nya pemahaman dalam melihat situasi cuaca, gelombang, jarang mengecek mesin sebelum berangkat, dan tidak mempunyai alat keselamatan yang lengkap. Indonesia merupakan negara kepuluan yang paling terbesar. Angkutan laut merupakan sarana tranportasi secara luar yang bisa digunakan untuk mendorong dan menunjang serta mengarahkan pertumbuhan sehingga memiliki sumber daya alam yang tinggi. Keselamatan 
pelayaran merupakan hal pertama yang harus diperhatikan dalam dunia pelayaran. Hal yang harus diperhatikan dalam pelayaran seperti, sikap, nilai, dan aktifatas mengenai pentingnya keselamatan dan keamanan. Penyebab rendahnya keselamatan pelayaran disebabkan oleh, rendahnya manajemen sumber daya manusia seperti, kopetensi, pendidikan, kondisi kerja, jam kerja dan jam proses (Suryani, et al, 2018).

Kecelakaan laut susah diprediksi dan bisa terjadi dimana saja. Untuk itu pihak kapal harus memperhatikan dan persiapan diantaranya, (1) mengikuti peraturan yang ada, (2) Cara penanggulangan saat darurat, (3) Pengecekan operasional (4) Cek kelayakan kapal, (5) Cek keadaan rantai dengan baik dan benar, (6) persiapan penerimaan Pilot (pandu),dan menurunkan Pilot, (7) cek smoke detector di anjungan untuk mengantisipasi kebakaran di palkapalka, (8) sebelum berlayar Peta-peta mulai dari tempat tolak sampai ketempat tujuan sudah dikoreksi dan up date, (9) pemeriksaan generator, tes running atau tidak, (10) pengecek lampulampu jalan dan lampu-lampu darurat, (11) mengetes darurat mesin Induk, (12) hasil Internal audit dan Manajemen review, (13) pengopersian Oil Water sparator (OWS), (14) menengecek tutup palka dan peralatan bongkar muat juga alat elektronik. Tujuan penelitian ini yaitu Cara penangugulangan atau peceggahan terjadinya kecelakaan laut serta meningkatkan SDM pelaut yang baik (HM Thamrin, AR, 2015).

Hal yang harus dipersiapakan seperti Safety equipment dengan mempersiapkan semua peralatan yang digunakan untuk melindungi awak kapal maupun penumpang agar disaat terjadi kecelakaan atau permasalahan saat pelayaran bisa menggunakan alat keselamatan dengan baik dan benar. Beberapa peralatan yang harus dipersiapankan seperti Life Jacket yaitu baju pelampung yang di kenakan oleh awak kapal atau penumpang untuk mengapungkan diri di dalam air pada waktu kapal berada dalam keadaan darurat. Berdasarkan data yang dikumpulkan bahwa sertifikat yang harus dipenuhi diatur dalam ketentuan International Convention for the Safety of Life at Sea (SOLAS), 1974, sebagaimana disebutkan juga dalam Undang- undang no.17
Tahun 2008, BAB IX tentang sertifikasi diantaranya, Dokumen Penyesuaian Manajemen Keselamatan (Document of Compliance), Sertifikat Manajemen Keselamatan ( Safety Man-agement Certificate) dan Sertifikat Keselamatan Kapal Penumpang( Passanger Ship Safety Certifikate) (Hendrawan andi 2019).

Dari beberapa penelitian terdahulu yang telah dijelaskan diatas, terdapat perbedaan yang signifikan dalam penelitian ini. Dimana focus penelitian ini adalah untuk meningkatkan keselamatan pelayaran dengan memperhatikan aturan aturan yang telah di tetapkan. Pada penelitian ini menggunakan metode mamdani dan aplikasi Software Matlab. Landasan Teori

\section{Landasan Teori}

\subsection{Keselamatan Pelayaran.}

Tingkat keselamatan merupakan hal yang harus diperhatikan. Sehingga mulai peraturan baru dengan istilah of Life at Sea yang mengatur tentang kebijakan keselamatan maritime hal pertama yang harus diperhatikan, untuk menjamin keselamatan di bagian kelautan. Pada tahun 1914 terjadi banyak kecelakaan kapal yang mengakibatkan korban jiwa maupun kelhilangan harta benda yang dimiliki. Peraturan ini mulai ditetapkan dengan berfokus pada peraturan kelengkapan navigasi, kekedapan dinding penyekat kapal serta peralatan berkomunikasi, Setelah itu ditemukan lagi penemuan yang sudah berkembang seperti konstruksi dan peralatan lainnya. Pada pengoperasian kapal banyak terjadi resiko kecelakaan laut yang cukup tinggi. Faktor penyebab kecelakaan pelayaran seperti, Desain konstruksi kapal, Permesinan dan instalasi listrik, Pencegah kebakaran, Alat-alat keselamatan(Hendrawan Andi, 2019).

Dalam proses keselamatan dan penyebrangan sudah di atur berdasarkan aturan yang telah di tetapkan. Jika permasalahan ini bisa di atasi maka kecelakaan pelayaran akan berkurang.Proses ini merupakan syarat utama dalam perancangan desain yang sudah dibuat.Permasalahan yang terjadi berupa kurang nya interaksi oleh berbagai pihak seperti pisah pemerintah, swasta maupun masyarakat umum dalam mencapai tinggkat kesalamat pelayaran yang tinggi(ketut I mudana, 2014). 
Sistem monitoring cuaca yang dirancang menggunakan sensor DHT11, arduino uno, dan Ethernet shield mampu menampilkan data monitoring dengan output realtime web pada pengujian tiap 10 jam. Penghitungan yang dihasilkan dengan metode fuzzy tidak jauh berbeda dengan prakiraan yang informasikan BMKG dengan persentasi keberhasilan pengujian data input sistem monitoring adalah $80,15 \%$. Tingkat keberhasilan sistem monitoring cuaca berbasis android dengan metode jaringan syaraf tiruan backpropagation adalah sebesar 78,6\% dari 14 data uji(Aisuwarya, Yendri, Kasoep, Amelia, \& Arifnur, 2016).

Sistem prakiraan cuaca yang dibuat mampu memprakirakan cuaca dengan menggunakan tiga parameter masukan yaitu suhu udara, kelembaban udara dan tekanan udara. Logika fuzzy metode Sugeno dapat diterapkan pada sistem prakiraan cuaca.Berdasarkan pengujian sistem prakiraan cuaca, hasil perbandingan prakiraan cuaca antara alat yang dibuat dengan kondisi cuaca sesungguhnya menghasilkan akurasi sebesar 74\%(Kurniati, 2017).

\subsection{Logika Fuzzy}

Logika fuzzy merupakan sebuah metode yang mudah dipahami dalam penyelesaian masalah dan dapat diimplementasikan kedalam sebuah system. Orang yang pertama kali menemukan logika fazzy adalah lutfi Zandeh pada tahun 1965. Logika fuzzy ini mampu menyelesaikan sebuah masalah untuk mendapatkan sebuah keputusan. Penelitian ini mengenalkan algoritma baru yang disebut Fuzzy Solid Linguistic Itemset Mining (FSLIM) untuk menemukan Solid Linguistic Itemsets (SLIs) dalam dataset kuantitatif. SLI adalah konsep baru yang diperkenalkan di sini sebagai bagian penting dari solusi yang disajikan dalam makalah ini. Metode yang diusulkan terdiri dari dua tahap. Pada fase pertama, teori himpunan fuzzy digunakan untuk mentransformasikan setiap nilai kuantitatif ke item linguistik; Dan pada fase kedua, semua SLI diekstraksi. Akhirnya, efisiensi FSLIM dibandingkan dalam hal waktu eksekusi, skalabilitas dan jumlah pola yang sering terjadi dengan dua pendekatan klasik pada dataset sintetis. Pendekatan yang diusulkan juga diterapkan pada kumpulan data Urban Masyhad yang sebenarnya untuk menggambarkan kemampuan FSLIM dalam menemukan pengetahuan tersembunyi yang tidak dapat diekstraksi dengan metode tradisional(Shakiba, Hooshmandasl, Davvaz, \& Fazeli, 2017).

Fuzzy Inference System berawal dari teori Fuzzy Set yang dikemukakan oleh Lofti Zadeh sekitar tahun 1965. Dengan Fuzzy Set, dapat direpresentasikan dan ditangani berbagai parameter ketidakpastian yang dalam hal ini bisa berarti keraguan, ketidaktepatan, kekuranglengkapan informasi, dan kebenaran yang bersifat sebagian. Adapun proses-proses yang berjalan dalam Fuzzy Inference System terdiri dari fuzzyfication, inference, dan defuzzyfication. Defuzzyfication pada penelitian ini menggunakan Weight Average method. Untuk menentukan batas membership function digunakan algoritma FCM sesuai dengan (Kudrat, Sibaroni, \& Time, n.d.).

Hasil dari penelitian ini membuktikan kegunaan dari FRBSs bahasa linguistic dalam sebuah perkembangan dan masalah signifikan dalam data mining seperti klasifikasi dataset yang tidak seimbang dan khusus untuk mereka dengan tingkat ketidakseimbangan yang tinggi (A. Fernandez, F. Herrera 2012).

Ada beberapa hal yang perlu diketahui dalam memahami sistem Fuzzy (Charolina, 2016):

a. Variabel Fuzzy

yaitu variabel yang hendak dibahas dalam suatu sistem Fuzzy, contoh: umur, temperatur, permintaan.

b. Himpunan Fuzzy

yaitu suatu group yang mewakili suatu kondisi atau keadaan tertentu dalam suatu variabel Fuzzy.

c. Semesta pembicaraan

yaitu keselutruhan nilai yang diperolehkan untuk dioperasikan dalam suatu variabel Fuzzy.

d. Domain

Yaitu keseluruhan nilai yang diizinkan dalam semesta pembicaraan dan boleh dioperasikan dalam suatu himpunan Fuzzy. 
Ada 3 operator yang diciptakan oleh Zadeh, yaitu Operator AND, Operator $O, R$ Operator NOT (Pangaribowo (2015).

Seperti halnya himpunan konvesional, ada beberapa operasi yang didefinisikan secara khusus untuk mengkombinasi dan memodifikasi himpunan Fuzzy. Nilai keanggotaan sebagai hasil dari operasi 2 himpunan sering dikenal dengan nama fire strength atau $\alpha$-predikat(Sri Kusuma dewi dan Hari Purnomo, 2010).

\subsection{Matlab}

XAMPP adalah perangkatlunak gratisMatlan Merupakan sebuah aplikasi yang mampu menganalisa sebuah logika fuzzy. Matlab ini merupakan sebuah perangkat lunak pada sebuah windows. Aplikasi metlab menyediakan berbagai menu diantaranya windows, antara lain Command Window, Current Directory Window, Workspace Window, Command History Window dan yg lainnya. Sebuah toolbox dalam MATLAB adalah koleksi berbagai fungsi MATLAB ( $M$-Files, yaitu file berekstensi), yang khusus pada bidang tertentu (Naba, 2009).

\section{Metode Penelitian}

Penelitian ini membutuhkan servai lansung untuk mendapatkan datang yang asli. Metode digunakan adalah metode Mamdani dengan proses penggunaan nilai terkecil ke nilai terbesar dengan operator or. Variabel pada penelitian ini menggunakan 4 variabel input diantaranya, cuaca, pengecekan mesin, kelengkapan alat, dan gelombang. Dengan hasil keluaran output perupa system pengambilan keputusan. Berdasarkan data yang diperoleh

\section{Hasil Dan Pembahasan}

Pada dasarnya kegiatan yang dilakukan pada tahapan analisis ini ada dua bagian,yaitu tahap pengumpulan data dan analisis terstruktur yang secara garis besar untuk memperoleh pengetian dari permasalahan-permasalahan, efisiensi dan pertimbangan-pertimbangan yang mengarah kepengembangan sistem. Memperkirakan kendala-kendala yang akan dihadapi dalam pengembangan sistem tersebut dan menentukan solusi-solusi alternatif pendalhuluan. Analisa sistem. Dalam menentukan keselamatan pelayaran di kepuluan Riau perlu dipersiapkan beberapa data yang diperlukan. Dari pengumpulan data yang sudah dilakukan, data yang diperlukan untuk berupa cara cara dalam meningkatkan keselamatan serta upaya mengurangi resiko kecelakaan yang akan terjadi. Data yang telah didapat akan dilakukan analisa sehingga data tersebut akan dikelompokkan menjadi kelompok-kelompok himpunan fuzzy yang bisa diolah denga merancang rule-rule menggunakan sistem fuzzy. Dalam hal ini adalah membahas tentang cara peningkatan keselamatan pelayaran di wilayah Batam, dari data yang sudah didapat maka dilakukan pengelompokan himpunan fuzzy. Pembahasan Fuzzy diawali dengan data dari pengolahan menggunakan metode Mamdani untuk menetapkan variabel, selanjutnya pembentukan himpunan fuzzy, setelah variabel ditetapkan dan himpunan fuzzy sudah dibentuk langkah selanjutnya adalah memasukan data ke aplikasi. Dalam menentukan perancangan sistem, terdapat 4 variabel input dan variabel output. Yang mana variabel input terdiri atas cuaca, Gelombang, Perawatan mesin, Peluang dan Perlengkapan Variabel output keputusan.

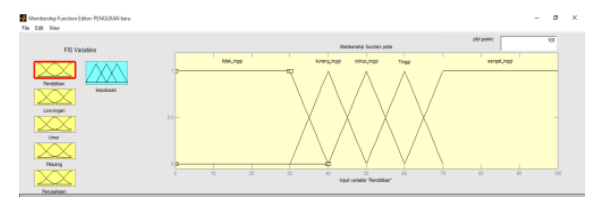

Gambar 2. Membership Function Untuk Variabel Cuaca Mamdani

Gambar ini menjelaskan implementasi variabel input dan output pada aplikasi Matlab 
Tabel 1. Hasil Analisis verifikatif dengan Matlab dan metode mamdani

\begin{tabular}{|c|c|c|c|}
\hline Variabel & $\begin{array}{c}\text { Nama Himpunan } \\
\text { Fuzzy }\end{array}$ & Domain & Semesta Pembicaraan \\
\hline \multirow[t]{4}{*}{ Cuaca } & Buruk & {$\left[\begin{array}{ll}0 & 19\end{array}\right]$} & {$\left[\begin{array}{llll}0 & 0 & 12 & 19\end{array}\right]$} \\
\hline & Sedang & {$\left[\begin{array}{ll}16 & 30\end{array}\right]$} & {$\left[\begin{array}{lll}16 & 23 & 30\end{array}\right]$} \\
\hline & Bagus & {$\left[\begin{array}{ll}27 & 40\end{array}\right]$} & {$\left[\begin{array}{llll}27 & 34 & 40 & 40\end{array}\right]$} \\
\hline & Tinggi & {$\left[\begin{array}{ll}0 & 9\end{array}\right]$} & {$\left[\begin{array}{llll}0 & 0 & 1 & 9\end{array}\right]$} \\
\hline \multirow{3}{*}{ Gelombang } & Sedang & {$\left[\begin{array}{ll}1 & 18\end{array}\right]$} & {$\left[\begin{array}{lll}1 & 9 & 18\end{array}\right]$} \\
\hline & Rendah & {$\left[\begin{array}{ll}9 & 20\end{array}\right]$} & {$\left[\begin{array}{llll}9 & 18 & 20 & 20\end{array}\right]$} \\
\hline & Sangat Disiplin & {$\left[\begin{array}{ll}60 & 100\end{array}\right]$} & {$\left[\begin{array}{lll}60 & 70 & 100\end{array}\right]$} \\
\hline \multirow{6}{*}{$\begin{array}{l}\text { Perawatan } \\
\text { Mesin }\end{array}$} & Disiplin & {$\left[\begin{array}{ll}50 & 70\end{array}\right]$} & {$\left[\begin{array}{ll}50 & 6070\end{array}\right]$} \\
\hline & Cukup Disiplin & {$\left[\begin{array}{ll}40 & 60\end{array}\right]$} & {$\left[\begin{array}{lll}40 & 50 & 60\end{array}\right]$} \\
\hline & Kurang Disiplin & {$\left[\begin{array}{lll}30 & 50\end{array}\right]$} & {$\left[\begin{array}{lll}30 & 40 & 50\end{array}\right]$} \\
\hline & Tidak Bagus & {$\left[\begin{array}{ll}0 & 40\end{array}\right]$} & {$\left[\begin{array}{lll}0 & 30 & 40\end{array}\right]$} \\
\hline & Sangat Lengkap & {$\left[\begin{array}{ll}50 & 100\end{array}\right]$} & {$\left[\begin{array}{lll}65 & 70 & 100\end{array}\right]$} \\
\hline & Lengkap & {$\left[\begin{array}{ll}30 & 70\end{array}\right]$} & {$\left[\begin{array}{llll}60 & 65 & 70\end{array}\right]$} \\
\hline \multirow[t]{2}{*}{ Perlengkapan } & $\begin{array}{l}\text { Cukup Lengkap } \\
\text { Kurang Lengkap } \\
\text { Tidak Lengkap }\end{array}$ & {$\left[\begin{array}{ll}0 & 50\end{array}\right]$} & $\begin{array}{l}{\left[\begin{array}{lll}55 & 60 & 65\end{array}\right]} \\
{\left[\begin{array}{llll}50 & 55 & 60\end{array}\right]} \\
{\left[\begin{array}{llll}0 & 0 & 50 & 55\end{array}\right]}\end{array}$ \\
\hline & Tinggi & {$\left[\begin{array}{ll}55 & 100\end{array}\right]$} & {$\left[\begin{array}{lll}55 & 70 & 100\end{array}\right]$} \\
\hline \multirow[t]{2}{*}{ Keputusan } & Sadang & {$\left[\begin{array}{ll}40 & 70\end{array}\right]$} & {$\left[\begin{array}{llll}40 & 55 & 70\end{array}\right]$} \\
\hline & Redah & {$\left[\begin{array}{ll}0 & 50\end{array}\right]$} & {$\left[\begin{array}{llll}0 & 0 & 40 & 50\end{array}\right]$} \\
\hline
\end{tabular}

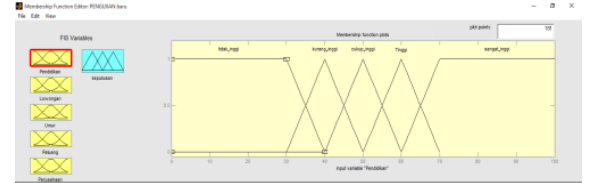

Gambar 2. Membership Function Untuk Variabel Cuaca Mamdani

Pada variabel Cuaca data yang dimiliki dapat dibagi menjadi 3 himpunan fuzzy, yaitu: Buruk, Sedang, Bagus. Himpunan fuzzy Buruk akan memiliki domain [ 0-49]. Himpunan fuzzy Sedang memiliki domain[16-30]. Himpunan fuzzy Bagus memiliki domain[27 40]. Bentuk perhitungan Cuaca secara manual :

$\mu$ Buruk $\quad=\left\{\begin{array}{lr}1 ; & x \leq 12 \\ \frac{19-x}{19-12} ; 20 \leq x \leq 19 \\ 0 ; \quad x \geq 19\end{array}\right.$

$$
\begin{aligned}
& \mu \text { Sedang }= \\
& \left\{\begin{array}{lr}
0 ; & x \leq 16 \text { atau } x \geq 30 \\
\frac{x-16}{23-16} ; & 16 \leq x \leq 23 \\
\frac{30-x}{30-23} ; & 23 \leq x \leq 30
\end{array}\right. \\
& \mu \text { Bagus } \quad=\left\{\begin{array}{lr}
0 ; & x \leq 27 \\
\frac{x-27}{34-27} ; & 27 \leq x \leq 34 \\
1 ; & 34 \leq x \leq 40
\end{array}\right.
\end{aligned}
$$

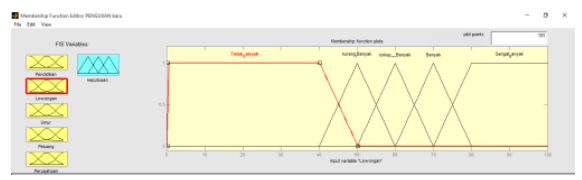

Gambar 3.Membership Function Untuk Variabel

\section{Gelombang}

Pada variabel Gelombangn data yang dimiliki dapat dibagi menjadi 3 himpunan fuzzy, , yaitu: Rendah, Sedang, Tinggi. Himpunan fuzzy Rendah akan memiliki domain [ 0-9]. Himpunan fuzzy 
Sedang memiliki domain[1 18]. Himpunan fuzzy Tinggi memiliki domain[9-20]. Bentuk perhitungan Gelombang secara manual :

$$
\begin{aligned}
& \mu \text { Rendah } \quad=\left\{\begin{array}{lr}
1 ; & x \leq 1 \\
\frac{9-x}{9-1} ; 1 & x \leq 9 \\
0 ; & x \geq 9
\end{array}\right. \\
& \mu \text { Sedang } \quad=\left\{\begin{array}{lc}
0 ; \quad x \leq 1 \text { atau } x \geq 18 \\
\frac{x-1}{9-1} ; & 1 \leq x \leq 9 \\
\frac{18-x}{18-9} ; & 9 \leq x \leq 18
\end{array}\right. \\
& \mu \text { Tinggi } \quad=\left\{\begin{array}{lr}
0 ; & x \leq 9 \\
\frac{x-9}{18-9} ; & 9 \leq x \leq 18 \\
1 ; & 18 \leq x \leq 20
\end{array}\right.
\end{aligned}
$$

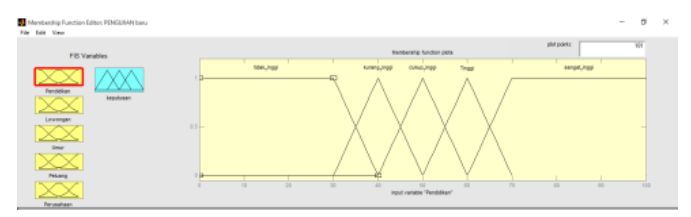

Gambar 4. Membership FunctionUntuk Variabel Perawatan Mesin

Pada variabel Perawatan mesin data yang dimiliki dapat dibagi menjadi 5 himpunan fuzzy, yaitu: Sangat Disiplin Disiplin, Cukup Disiplin, Kurang Disiplin, Tidak Disiplin. Himpunan fuzzy tidak Disiplin akan memiliki domain [ 0-40]. Himpunan fuzzy kurang Disiplin memiliki domain[30-50]. Himpunan fuzzy cukup Disiplin memiliki domain[40 60]. Himpunan fuzzy Disiplin memiliki domain[50-70]. Himpunan fuzzy Sangat Disiplin memiliki domain[60-100]. Bentuk perhitungan Perawatan Mesin secara manual :

$\mu$ Tidak Disiplin $=$

$$
\left\{\begin{array}{lc}
1 ; & x \leq 30 \\
(40-x 1) /(40-30) & 30 \leq x \leq 40 \\
0 ; & \leq x 40
\end{array}\right.
$$

$\mu$ Kurang Disiplin $=$

$\begin{cases}0 ; & x \leq 30 \text { atau } x \geq 50 \\ (x-50) /(40-30) ; & 30 \leq x \leq 50 \\ (50-x) /(50-40) ; & 40 \leq x \leq 50\end{cases}$

$\mu$ Cukup Disiplin $=$

$\begin{cases}0 ; & x \leq 40 \text { atau } x \geq 60 \\ (x-40) /(50-40) ; & 40 \leq x \leq 60 \\ (40-x) /(60-50) ; & 50 \leq x \leq 60\end{cases}$

$\mu l$ Disiplin =

$\begin{cases}0 ; & x \leq 60 \text { atau } x \geq 70 \\ (x-50) /(60-50) ; & 60 \leq x \leq 50 \\ (70-x) /(70-60) ; & 60 \leq x \leq 70\end{cases}$

$\mu$ Sangta Disiplin $=$

$$
\begin{cases}0 ; & x \leq 60 \\ (x-60) /(70-60) ; & 60 \leq x \leq 70 \\ 1 ; & x \geq 70\end{cases}
$$

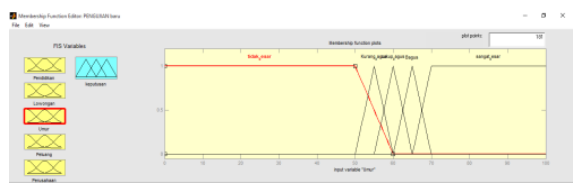

Gambar 5.Membership FunctionUntuk Variabel

Alat Pengaman

Pada variabel Perawatan mesin data yang dimiliki dapat dibagi menjadi 5 himpunan fuzzy, yaitu: Sangat Disiplin Disiplin, Cukup Disiplin, Kurang Disiplin, Tidak Disiplin. Himpunan fuzzy tidak Disiplin akan memiliki domain [ 0-40]. Himpunan fuzzy kurang Disiplin memiliki domain[30-50]. Himpunan fuzzy cukup Disiplin memiliki domain[40 60]. Himpunan fuzzy Disiplin memiliki domain[50-70]. Himpunan fuzzy Sangat Disiplin memiliki domain[60-100]. Bentuk perhitungan Perawatan Mesin secara manual : 
$\mu$ Tidak Disiplin $=$

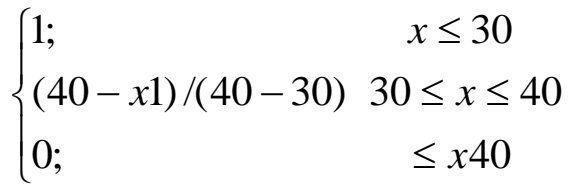

$\mu$ Kurang Disiplin $=$

$\begin{cases}0 ; & x \leq 30 \text { atau } x \geq 50 \\ (x-50) /(40-30) ; & 30 \leq x \leq 50 \\ (50-x) /(50-40) ; & 40 \leq x \leq 50\end{cases}$

$\mu$ Cukup Disiplin $=$

$\begin{cases}0 ; & x \leq 40 \text { atau } x \geq 60 \\ (x-40) /(50-40) ; & 40 \leq x \leq 60 \\ (40-x) /(60-50) ; & 50 \leq x \leq 60\end{cases}$

$\mu l$ Disiplin $=$

$\begin{cases}0 ; & x \leq 60 \text { atau } x \geq 70 \\ (x-50) /(60-50) ; & 60 \leq x \leq 50 \\ (70-x) /(70-60) ; & 60 \leq x \leq 70\end{cases}$

$\mu$ Sangta Disiplin $=$

$\begin{cases}0 ; & x \leq 60 \\ (x-60) /(70-60) ; & 60 \leq x \leq 70 \\ 1 ; & x \geq 70\end{cases}$

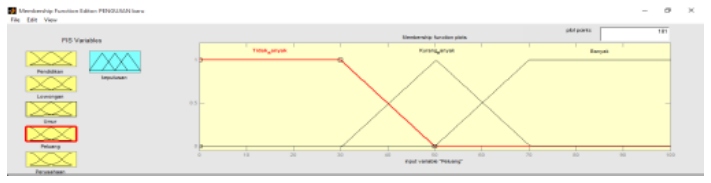

Gambar 6. Membership Function Untuk

Variabel Keputusan

Pada variabel Keputusan data yang dimiliki dapat dibagi menjadi himpunan fuzzy, yaitu: Kecil, Sedang, Besar. keanggotaan Kecil, Himpunan fuzzy Kecil akan memiliki domain [ 075 dengan derajat keanggotaan tidak Kecil. Himpunan fuzzy Sedang akan memiliki domain [ 60-90],. Himpunan fuzzy Besar memiliki domain [ 75-100].

Bentuk perhitungan Keputusan secara manual sebagai berikut :

$\mu$ Kecil $=\left\{\begin{array}{lc}1 ; & x \leq 30 \\ (50-x) /(50-30) & 30 \leq x \leq 50 \\ 0 ; & \leq x 50\end{array}\right.$

$\mu$ Sedang $=$

$\begin{cases}0 ; & x \leq 30 \text { atau } x \geq 70 \\ (x-30) /(50-30) ; & 30 \leq x \leq 50 \\ (70-x) /(70-50) ; & 50 \leq x \leq 70\end{cases}$

$\mu$ Besar =

$\left\{\begin{array}{lc}1 ; & x \leq 50 \\ (50-x) /(70-50) & 50 \leq x \leq 70 \\ 0 ; & \leq x 70\end{array}\right.$

\section{Mesin Inferensi}

Berikut aturan - aturan yang terbentuk dari inferensi fuzzy bisa dilihat di tabel. 
Tabel 2. Aturan - Aturan Yang Terbentuk Dari Inferensi Fuzzy

\begin{tabular}{cccccc}
\hline Aturan & Cuaca & Gelombang & Perawatan Mesin & Perlengkapan & Keputusan \\
\hline R1 & Buruk & Rendah & Tidak Disiplin & Tidak Lengkap & Tinggi \\
R2 & Buruk & Rendah & Tidak Disiplin & Cukup Lengkap & Tinggi \\
R3 & Buruk & Rendah & Tidak Disiplin & Sangat Lengkap & Tinggi \\
R4 & Buruk & Rendah & Cukup Disiplin & Tidak Lengkap & Tinggi \\
R5 & Buruk & Rendah & Cukup Disiplin & Cukup Lengkap & Tinggi \\
R6 & Buruk & Rendah & Cukup Disiplin & Sangat Lengkap & Tinggi \\
R7 & Buruk & Rendah & Sangat Disiplin & Tidak Lengkap & Tinggi \\
R8 & Buruk & Rendah & Sangat Disiplin & Cukup Lengkap & Tinggi \\
R9 & Buruk & Rendah & Sangat Disiplin & Sangat Lengkap & Tinggi \\
R10 & Buruk & Sedang & Tidak disiplin & Tidak Lengkap & Tinggi \\
R11 & Buruk & Sedang & Tidak disiplin & Cukup Lengkap & Tinggi \\
R12 & Buruk & Sedang & Tidak disiplin & Sangat Lengkap & Tinggi \\
R13 & Buruk & Sedang & Cukup Disiplin & Tidak Lengkap & Tinggi \\
R14 & Buruk & Sedang & Cukup Disiplin & Cukup Lengkap & Tinggi \\
R15 & Buruk & Sedang & Cukup Disiplin & Sangat Lengkap & Tinggi \\
R16 & Buruk & Sedang & Sangat Disiplin & Tidak Lengkap & Tinggi \\
R17 & Buruk & Sedang & Sangat Disiplin & Cukup Lengkap & Tinggi \\
R18 & Buruk & Sedang & Sangat Disiplin & Sangat Lengkap & Tinggi \\
R19 & Buruk & Tinggi & Tidak disiplin & Tidak Lengkap & Tinggi \\
R20 & Buruk & Tinggi & Tidak disiplin & Cukup Lengkap & Tinggi \\
\hline
\end{tabular}

\section{Implikasi}

Langkah pertama adalah mencari derajat keanggotaan masing-masing variabel.

a. Cuaca, terdiri dari 3 himpunan fuzzy, yaitu untuk, sedang dan Bagus. Jika diketahui Cuaca 31, maka nilai keanggotaan fuzzy 31 pada tiap-tiap himpunan adalah:

$$
\begin{aligned}
\mu \text { Buruk } & =0 \\
\mu \text { Sedang } & =0 \\
\mu \text { Bagus } & =(\mathrm{x}-\mathrm{a}) /(\mathrm{b}-\mathrm{a}) \\
& =(31-27) /(34-27) \\
& =4 / 7 \\
& =0,57
\end{aligned}
$$

b. Gelombang, terdiri dari 3 himpunan fuzzy, yaitu Tinggi, sedang dan Kecil. Jika diketahui Gelombang 97, maka nilai keanggotaan fuzzy 97 pada tiap-tiap himpunan adalah:

$$
\begin{aligned}
\mu \text { Kecil } & =0 \\
\mu \text { Sedang } & =(\mathrm{c}-\mathrm{x}) /(\mathrm{c}-\mathrm{b}) \\
& =(99-97) /(99-84) \\
& =2 / 15 \\
& =0,13 \\
\mu \text { Tinggi } & =((\mathrm{x}-\mathrm{a}) /(\mathrm{b}-\mathrm{a}) \\
& =(97-84) /(99-84) \\
& =13 / 15 \\
& =0,86
\end{aligned}
$$

c. Perawatan Mesin terdiri dari 5 himpunan fuzzy, yaitu Tidak disiplin, Cukup disiplin, Kurang disiplin, Disiplin, Dan sangat disiplin. Jika diketahui Perawatan 
mesin 80 , maka nilai keanggotaan fuzzy 80 pada tiap-tiap himpunan adalah: $\mu$ Tidak disiplin $=0$

$\mu$ Kurang disiplin $=0$

$\mu$ Cukup Disiplin $\quad=0$

$\mu$ Disiplin $\quad=(\mathrm{c}-\mathrm{x}) /(\mathrm{c}-\mathrm{b})$

$=(80-80) /(80-80)$

$=0 / 0$

$=1$

$$
\begin{aligned}
\mu \text { Sangat disiplin } & =(\mathrm{c}-\mathrm{x}) /(\mathrm{c}-\mathrm{b}) \\
& =(90-90) /(90-90) \\
& =0 / 0 \\
& =1
\end{aligned}
$$

d. Perlengkapan terdiri dari 5 himpunan fuzzy, yaitu Tidak Lengkap, Cukup Lengkap, Kurang Lengkap, Lengkap, Dan Lengkap. Jika diketahui Perlengkapan 65, maka nilai keanggotaan fuzzy 65 pada tiap-tiap himpunan adalah: $\mu$ Tidak disiplin $=0$

$$
\begin{array}{ll}
\mu \text { Kurang disiplin } & =0 \\
\begin{aligned}
\mu \text { Cukup Disiplin } & =0 \\
& =(\mathrm{c}-\mathrm{x}) /(\mathrm{c}-\mathrm{b}) \\
& =(70-65) /(70-60) \\
& =5 / 10 \\
= & 0,2
\end{aligned}
\end{array}
$$

$$
\begin{aligned}
\mu \text { Sangat disiplin } & =(\mathrm{x}-\mathrm{a}) /(\mathrm{b}-\mathrm{a}) \\
& =(65-65) /(70-65) \\
& =0 / 5 \\
& =0
\end{aligned}
$$

Dari hasil fuzzification menghasilkan3 fuzzy input yaitu :

1. Cuaca $=$ Buruk (0), Sedang(0) dan Bagus $(0,57)$

2. Gelombang $=\operatorname{Besar}(0,13)$, Sedang $(0,86)$ dan Kecil (0)

3. Perawatan Mesin= Sangat Disiplin (1), Disiplin (1), Cukup disiplin(0), Kurang Disiplin (0), Tidak disiplin $(0,75)$

4. Perlengkapan $=$ Sangat Lengkap $(0,2)$, Lengkap (0), Cukup Lengkap (0), Kurang Lengkap(0), Tidak disiplin(0).
Langkah kedua adalah menerapkan fungsi implikasi untuk mendapatkan modifikasi output daerah fuzzy dari setiap rule yang berlaku. Fungsi implikasi yang digunakan adalah metode Min. Rule yang terpengaruh nilai derajat keanggotaan adalah sebagai berikut.

[R14] if Cuaca, Bagus or Gelombang kecil, or Perawatan mesin sangat disiplin, or Perelengkapan sangat lengkap then Tingkat Keselamatan Tinggi.

$\alpha_{2}=\mu_{\text {CuacaBagus }} \cap \mu_{\text {Perlengkapansangat lengkap }} \cap$

$\mu_{\text {PerawatanMesinSangatdisiplin }} \cap$

$\mu_{\text {Perlengkapansangat lengkap }}$

$=\min \left(\mu_{\text {CuacaBagus }}[31] \cap \mu_{\text {Gelomagkecil }}[97] \cap\right.$

$\mu p_{\text {erawatanMesinSangatdisiplin }}[80] \cap$

$\mu_{\text {Perlengkapansangat lengkap }}[65]$

$=\min (0,57 \cap 0 \cap 1 \cap 0)$

$=0$

[R14] if Cuaca Bagus, or Gelombang sedang ,or Perawatan mesin sangat disiplin, or Perelengkapan sangat lengkap then Tingkat Keselamatan Tinggi.

$\alpha_{2} \quad=\mu_{\text {CuacaBagus }} \cap \mu_{\text {Gelomagkecil }} \cap$

$\mu_{\text {PerawatanMesinSangatdisiplin }} \cap$

$\mu_{\text {Perlengkapansangat lengkap }}$

$=$

$\min \left(\mu_{\text {CuacaBagus }}[31] \cap \mu_{\text {Gelomagkecil }}[97] \cap\right.$

$\mu p_{\text {erawatanMesinSangatdisiplin }}[80] \cap$

$\mu_{\text {Perlengkapansangat lengkap }}[65]$

$=\min (0,57 \cap 0.86 \cap 1 \cap 0)$

$=0$

[R14] if Cuaca Bagus, or Gelombang sedang ,or Perawatan mesin Tidak disiplin, or Perelengkapan sangat lengkap then Tingkat Keselamatan Tinggi.

$$
\begin{aligned}
& \alpha_{2} \quad=\mu_{\text {CuacaBagus }} \cap \mu_{\text {Gelomagkecil }} \cap \\
& \mu_{\text {PerawatanMesintidakdisiplin }} \cap \\
& \mu_{\text {Perlengkapansangat lengkap }} \\
& = \\
& \min \left(\mu_{\text {CuacaBagus }}[31] \cap \mu_{\text {Gelomagkecil }}[97] \cap\right. \\
& \mu p_{\text {erawatanMesinSangatdisiplin }}[80] \\
& \cap \mu_{\text {Perlengkapansangat lengkap }}[65] \\
& =\min (0,57 \cap 0.86 \cap 0.75 \cap 0) \\
& =0
\end{aligned}
$$

[R14] if Cuaca Bagus, or Gelombang sedang ,or Perawatan mesin sangat disiplin, or Perelengkapan sangat lengkap then Tingkat Keselamatan Tinggi.

$$
\begin{aligned}
& \alpha_{2} \quad=\mu_{\text {CuacaBagus }} \cap \mu_{\text {Gelomagkecil }} \cap \\
& \mu_{\text {PerawatanMesinSangatdisiplin }} \cap \\
& \mu_{\text {Perlengkapansangat lengkap }}
\end{aligned}
$$




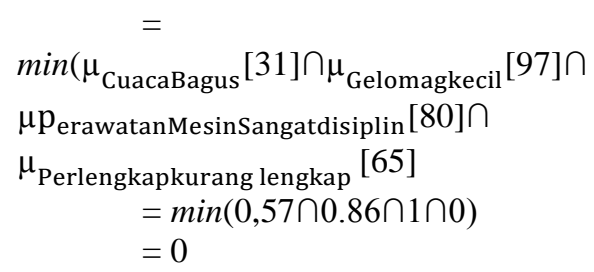

\section{Defuzzifikasi}

Pada tahap defuzifikasi merupakan tahap terakhir dalam pencarian fuzzy. Hasil ini diperoleh dari penentuan input, proses, rule serta pencarian nilai terakhir.

Langkah ketiga adalah menghitung hasil akhir dengan menggunakan metode centroid, yaitu:

$$
\begin{aligned}
\text { M1 } & =\int_{0}^{36,6}(0,33) ; z d z \\
= & 0,16 \mathrm{z}^{2} \mathrm{dz} \\
= & 0,16(36,6)^{2}-0,16(0)^{2} \\
= & 214,3296 \\
= & \int_{36,6}^{43,2} \frac{z-30}{20} z d z \\
= & \left(0,05 \mathrm{z}^{2}-1,5 \mathrm{z}\right) \mathrm{dz} \\
= & 0,01667 \mathrm{z}^{3}-0,75 \mathrm{z}^{2} \\
= & \left(0,01667(43,2)^{3}-0,01667(36,6)^{3}\right)- \\
& \left(0,75(43,2)^{2}-0,75(36,6)^{2}\right) \\
= & (1343,96154-817,29503)-(1399,68- \\
& 1004,67) \\
= & 526,66651-395,01 \\
= & 131,19611 \\
= & \int_{43,2}^{100}(0,66) z d z \\
= & 0,33 \mathrm{z}^{2} \mathrm{dz} \\
= & \left(0,33(100)^{2}\right)-\left(0,33(43,2)^{2}\right) \\
= & 3300-615,8592 \\
= & 2684,1408 \\
\text { M3 } &
\end{aligned}
$$

Kemudian kita hitung luas setiap daerah:

$$
\begin{aligned}
\mathrm{A} 1 & =36,6 \times 0,33 \\
& =12,078
\end{aligned}
$$

Proses pencarian nilai implikasi fungsi aplikasi pertama

$$
\text { A2 } \quad \begin{aligned}
= & (0,33+0,66) \times(43,2-36,6) / 2 \\
& =0,99 \times 6,6 / 2 \\
& =0,99 \times 3,3 \\
& =3,267
\end{aligned}
$$

Proses pencarian nilai implikasi dan aplikasi Kedua

$$
\begin{aligned}
\mathrm{A} 3 & =(100-43,2) \times 0,66 \\
& =56,8 \times 0,66 \\
& =37,488
\end{aligned}
$$

Proses pencarian nilai implikasi dan aplikasi Ketiga

Titik pusat dapat diperoleh dari:

$$
\begin{aligned}
z & = \\
& =\frac{214,3296+131,19611+2684,1408}{12,078+3,267+37,488} \\
Z & =\frac{3029,666651}{52,833} \\
\mathbf{Z} & =\mathbf{5 7 , 3 4 4 2 1}
\end{aligned}
$$

Hasil ouput nilai fuzzy dalam proses defuzification mendapatkan nilai sebesar 57.34421 dengan hasil keputusan tingkat keselamatan tinggi. Nilai ini diperoleh dari hasil proses matematikadan himpunan logika fuzzy.

\section{Kesimpulan}

Berdasarkan hasil penelitian dan pengujian yang dilakukan di dapatkan nilai akhir defuzifikasi sebesar 57,34421. Hasil ini diperoleh dari empat variabel yaitu cuaca, gelombang, pengecekan mesin dan Perlengkapan peralatan.. Nilai inputan yang dimasukkan sesuai dengan data yang diperoleh mendapatkan nilai tingkat kecelakaan pelayaran di kota batam Tinggi sehingga diperlukan perbaikan serta pihak pihat terkait harus mengikuti prosedur dan aturan yang telah di tetapkan. 


\section{Ucapan Terima Kasih}

Kami menyampaikan terima kasih kepada beberapa pihak:

1. Simlitabmas Dikti yang memberikan pendanaan penelitian pada penelitian dosen pemula.

2. Universitas Putera Batam yang telah memberikan fasilitas maupun dukungan.

\section{Daftar Referensi}

Aisuwarya, R., Yendri, D., Kasoep, W., Amelia, K., \& Arifnur, A. A. (2016). BERBASIS MIKROKONTROLER, (November), 1-9. Charolina, Y. (2016). Sistem Pendukung Keputusan Untuk Menentukan Pemberian Bonus Tahunan Menggunakan Metode Fuzzy Logic Tipe Mamdani. Teknologi Informasi, 12(2),

Fernandez, A., \& Herrera, F. (2012). Linguistic Fuzzy Rules in Data Mining: Follow-Up Mamdani Fuzzy Modeling Principle. Combining Experimentation and Theory, 103-122.

Hendrawan, A., \& Nusantara, A. M. (2019). Analisa indikator keselamatan pelayaran pada kapal niaga, (January).

Ketut, I mudana, (2014). Peningkatan Pengawasan Keselamatan Angkutan Penyeberangan Lintas Palembang-Muntok, Jurnal manajemen tranportasi dan logistic.

Kudrat, S. N., Sibaroni, Y., \& Time, F. (n.d.). Simulasi Pengaturan Lampu Lalu Lintas Menggunakan Cellular Automata Dan Fuzzy Inference System Traffic Light Control Simulation Using.

Kusumadewi, S. (2010). Aplikasi Logika Fuzzy untuk Pendukung Keputusan (2nd ed.). Yogyakarta.

Kurniati, V. (2017). Weather is one of the important factors in supporting human activities . The difference of weather between another place caused by the changes of air temperature, humidity and air pressur. Parameters that are considered for predicting weather are air t, 5(2), 119-128.

Pangaribowo, T. (2015). Perancangan Simulasi Kendali Valve Dengan Algoritma Logika
Fuzzy Menggunakan Bahasa Visual Basic. Teknologi Elektro, 6(2), 123-135.

Naba, A. (2009). Belajar cepat Fuzzy Logic Menggunakan MATLAB. (S. Suryanto, Ed.). Yogyakarta: Andi.42-53.

Shakiba, A., Hooshmandasl, M. R., Davvaz, B., \& Fazeli, S. A. S. (2017). S-approximation spaces: a fuzzy approach. Iranian Journal of Fuzzy Systems, 14(2), 127-154.

Thamrin, H. M. (2015). Pencegahan Kecelakaan Kapal Ke Titik Nol ( Zero Accident ). Jurnal Ilmiah Widya, 3, 110-116. 